\title{
SOME OBSERVATIONS ON THE USE OF THE NUNN BLOOD GAS PREDICTOR
}

\section{J W R McIntyre, f f a R C s, and George Drummond, $\mathrm{m}$ B , CH B *}

ThE RELATIONSHIP between ventilation and the arterial $\mathrm{pH}$ and $p \mathrm{CO}_{2}$ of healthy patients has sometmes been portrayed, together with other relevant factors, in the form of a nomogram 'The use of one of these facilitates the adjustment of ventilation required to produce a desired $\mathrm{pH}$ and $p \mathrm{CO}_{2}$, or assessment of the probable effects of existing ventilation In 1955 Radford published a nomogram

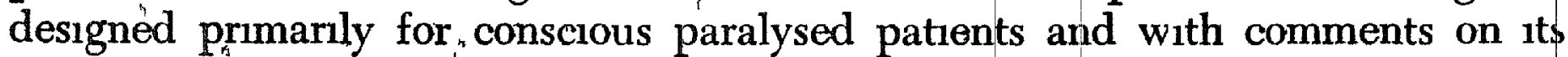
use in other crrcumstances, These have been elaborated by Scurr, ${ }^{2} \mathrm{Nunn},{ }^{3}$ and Gain ${ }^{4}$ Other nomograms have been presented for use in anaesthesia by Engstrom, ${ }^{56}$ and Nunn has described a blood gas predictor in the form of a slide rule $^{7}$ The predictions of the latter are based on the body weight, sex, metabolic rate, and ventilation of the patient The alveolar ventilation is calculated as 07 of the minute volume, and the $\mathrm{pH}$ piediction is based on the Henderson-Hesselbalch equation No correction for intubation is considered necessary Some

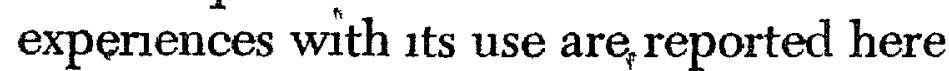

Forty healthy normothermic patients undergoing extrathoracic surgery, having been premedicated with morphine or meperidine and atropine, were induced with thiopentone and succinylcholine, intubated, and maintained under anaesthesia with a $2 \mathrm{~L} / \mathrm{mm}$ flow of nitrous oxide and oxygen 11 , carrying methoxyflurane 0 75-1 0 per cent into a semi-closed circle system B O C machines with Folegger Jumbo carbon dioxide absorbers and Jefferson ventilators were used Ventlation was maintained at a constant rate and volume, the former varying between 12 and $20 / \mathrm{mm}$, the latter selected at random and measured with a Wright anemometer Systemic blood pressure remained stable at near normal values and transfusions were not given After an hour of stable ventilation the $\mathrm{pH}$ and $p \mathrm{CO}_{2}$ of arterial samples were measured with munimal delay using an AME I Astrup micro-equipment $\mathrm{pH}$ metel and a Sigaard Anderson and Engel nomogram

The true ventilation minute volume was taken as the anemometer reading reduced by 10 per cent as compensation for expansion of corrugated tubing The alveolar ventilation was calculated as 07 of the minute volume ${ }^{3}$ It was assumed that patients under these conditions had their metabolism reduced to 85 per cent of normal and this, together with the minute volume, sex, and body weight, was used to predict the $p \mathrm{CO}_{2}$ and $\mathrm{pH}$ with the shde rule

The results (Table I) are considered here from two aspects first, the diffe1ence between the predicted values and those obtained from arterial blood samples, secondly, the usefulness of the shide rule in predicting the ventilation necessary to maintain a $p \mathrm{CO}_{2}$ at approximately $40 \mathrm{~mm} \mathrm{Hg}$ The predicted $p \mathrm{CO}_{2}$ was

*Department of Anaesthesia, University of Alberta Hospital, Edmonton, Alberta 
TABLE I

\begin{tabular}{|c|c|c|c|}
\hline & $\begin{array}{l}\text { Prediction using } \\
\text { minute volume }\end{array}$ & & $\begin{array}{l}\text { Prediction using } \\
\text { alveolar ventilation }\end{array}$ \\
\hline $\begin{array}{l}\text { Difference between predicted } \\
\text { and measured } \mathrm{pH}\end{array}$ & $\begin{array}{l}\text { Average mean } \\
\text { Standard devialıon } \\
\text { Standard error of mean }\end{array}$ & $\begin{aligned} &+ 010 \\
& 0005 \\
& 0008 \\
& p<0001\end{aligned}$ & $\begin{array}{r}+011 \\
0046 \\
0007 \\
<0001\end{array}$ \\
\hline $\begin{array}{l}\text { Difference between predicted } \\
\text { and measured } p \mathrm{CO}_{2}\end{array}$ & $\begin{array}{l}\text { Average mean } \\
\text { Standard deviation } \\
\text { Standard error of mean }\end{array}$ & $\begin{array}{r}-195 \\
405 \\
064 \\
p<0001\end{array}$ & $\begin{aligned}-28 \\
419 \\
066 \\
<0001\end{aligned}$ \\
\hline
\end{tabular}

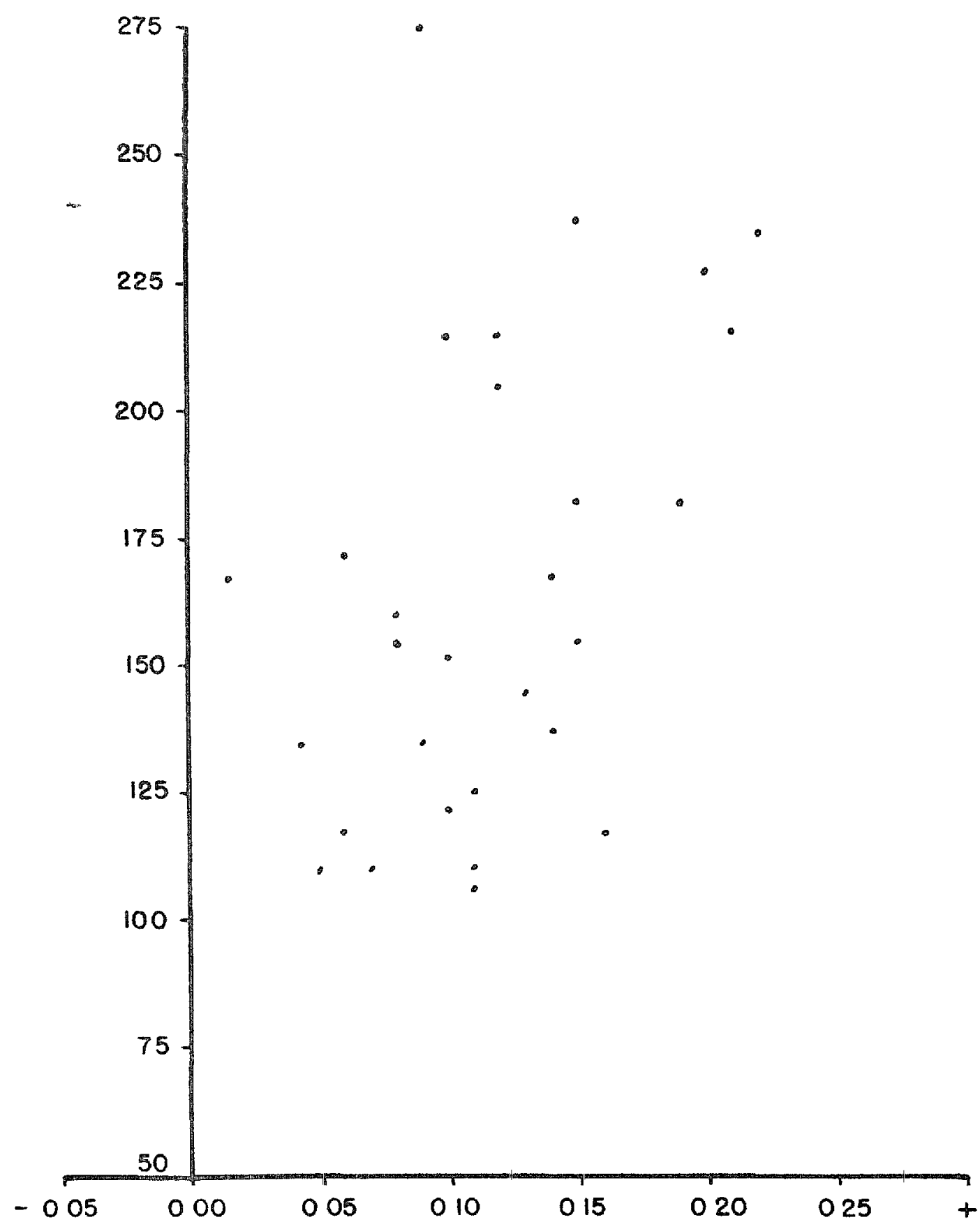

Figure 1 Percentage value of tıdal volume used agannst the predicted volume necessary to maintain $\mathrm{pCO}_{2}$ at $400 \mathrm{~mm} \mathrm{Hg}$ (ordinate) versus the difference between the predicted $\mathrm{pH}$, based on minute volume, and measured value from artenal blood (abscissa) 
always lower than the measured value The variation in difference could not be correlated with body weight, sex, or with rate of ventilation However, an approximately linear relationship with the degree of hyperventlation could be demonstrated (Figs 1,2) The hyperventilation was calculated as the percentage of the predicted value necessary to mantain a $p \mathrm{CO}_{2}$ of $40 \mathrm{~mm} \mathrm{Hg}$, and as hyperventalation was increased so the measured $p \mathrm{CO}_{2}$ was progressively higher than the predicted value

It was found that to mantam a $\mathrm{pCO}_{2}$ of $35-45 \mathrm{~mm}$ Hg. ventllation had to be increased to $105-130$ per cent of the value predicted as necessary to mantan a $\mathrm{pCO}_{2}$ of $40 \mathrm{~mm} \mathrm{Hg}$

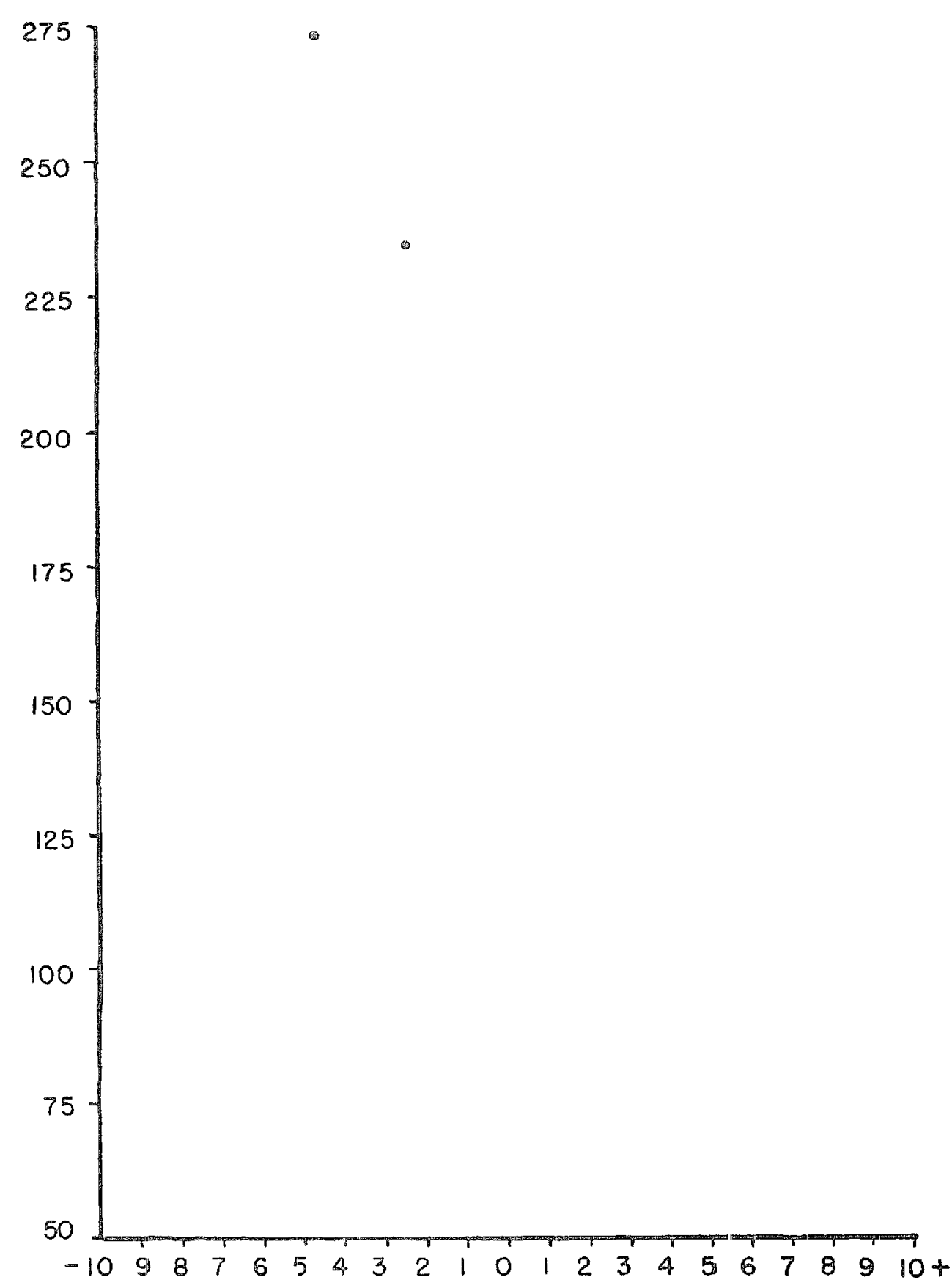

Figure 2 Percentage value of tadal volume used against the predicted volume needed to maintain a $p \mathrm{CO}_{2}$ of $400 \mathrm{~mm} \mathrm{Hg}$ (ordinate) versus the difference between the predicted $\mathrm{pCO}_{2}$, based on munute volume, and measured value from artenal blood (abscissa)

A number of reasons, such as errors in the technique of blood gas analysis or measurement of ventilation, may account for these variations. It is considered 
unlikely that there was an increasing distension of the corrugated tubing with hyperventilation because muscle relaxants were used to produce maximum pulmonary comphance and there was considerable variation in pressures required to produce similar ventilation in different patients More probable reasons are an increase in physiological dead space above that used in the design of the predictor, and in carbon dioxide output Methoxyflurane has been reported as responsible for only a slight trend towards metabolic acidosis ${ }^{9}$ or failure to disturb it significantly ${ }^{10}$ However, specific effects of this drug may in part account for the increase in ventilation above that predicted on the slide rule, which was required to maintain a $p \mathrm{CO}_{2}$ at approximately $40 \mathrm{~mm} \mathrm{Hg}$

Nunn has carefully outlined the sources of error in the use of this predictor and emphasized that it indicates what the $\mathrm{CCO}_{2}$ might reasonably be expected to be and not what it is The findings presented here suggest that this is indeed so and that, when used in the manner described, the predictor will read low for $p \mathrm{CO}_{2}$ and high for $\mathrm{pH}$, particularly if a hyperventilation technique is being used The experienced anaesthetist can provide adequate ventulation in uncomplicated cases without recourse to a nomogram or blood gas analysis ${ }^{4}$ The value of the Nunn predictor lies in the fact that it encourages the anaesthetist in training to correlate, in a normal case, the clinical signs of ventilation with what the $p \mathrm{CO}_{2}$ and $\mathrm{pH}$ might possibly be, and it provides a clinical standard of ventilation for reference purposes

\section{SUMMARY}

In 1962 Nunn described a predictor for arterial $p \mathrm{CO}_{2}$ and $\mathrm{pH}$ This was in the form of a slide rule and its function was based on the patient's weight, sex, metabolic rate, and ventilation A clinical investigation of 40 healthy patients undergoing extrathoracic surgery was performed The anaesthetic technique consisted of thiopentone, nitrous oxide, methoxyflurane, relaxant, and artificial ventilation After one hour predicted values of $p \mathrm{CO}_{2}$ and $\mathrm{pH}$ were compared with those measured from arterial blood samples The predicted $p \mathrm{CO}_{2}$ was always lower than the measured value, and the difference increased with the degree of hyperventlation It was found that to maintain a $p \mathrm{CO}_{2}$ of $35-45$ $\mathrm{mm} \mathrm{Hg}$ ventilation had to be increased to $105-130$ per cent of the value predicted necessary to maintain a $p \mathrm{CO}_{2}$ of $40 \mathrm{~mm} \mathrm{Hg}$ These findings were considered to be mainly due to an increase in physiological dead space, and an increase in carbon dioxide production during methoxyflurane anaesthesia

\section{RÉSUMÉ}

En 1962, Nunn a mis au point un apparell pouvant renseigner su la $p \mathrm{CO}_{2}$ et le $\mathrm{pH}$ du sang arténel Cet apparell ressemble à une règle à calcul, et son fonctionnement est basé sur le poids, le sexe, le métabolısme basal et la ventılation du malade Nous avons fait des recherches cliniques chez 40 sujets sains qui devaient subir de la chirurgıe extrathoracique Nous avons utılısé la technıque survante pentothal, protoxyde d'azote, méthoxyflurane, myorésolutif et ventilation artificielle Au bout d'une heure d'anesthésie, nous avons comparé les don- 
nées prédites par la règle à calcul de la $p \mathrm{CO}_{2}$ et du $\mathrm{pH}$ avec celles quı avarent été obtenues sur des échantillons de sang artériel $\mathrm{La} p \mathrm{CO}_{2}$ prédite était toujours mférieure à la $p \mathrm{CO}_{2}$ mesurée $\mathbb{L a}$ dufférence augmentaıt avec l'importance de lhyperventulation Nous avons compris que pour mantenur une $p \mathrm{CO}_{2}$ de 35 à 45 $\mathrm{mm}$ de mercure, il fallait augmenter la ventilation de 105 à 130 pour cent de la valeur nécessaire prédite pour maintenır une $p \mathrm{CO}_{2}$ à $40 \mathrm{~mm}$ de mercure Ces résultats seraient attribuables en grande partie à l'augmentation de l'espace mort physiologique et à l'augmentation de la production du $\mathrm{CO}_{2}$ au cours de l'anesthésı au méthoxyflurane

\section{REFERENCES}

1 RADFORD, E P JR Ventilation Standards for Use in Artificial Ventalation J Appl Physiol 7 451 (1955)

2 Scurr, C F Controlled Respiration Standards of Ventilation Bint J Anaesth 28422 (1956)

3 Nunn, J F Prediction of Carbon Dioxide Tension durng Anaesthesia Anaesthesia 15 123 (1960)

1 GAIN, E A The Adequacy of the Radford Nomogram dunng Anaesthesia Canad Anaesth Soc J 10491 (1963)

5 Engstrom, C-G \& HerzoG, P Ventlation Nomogram for Practical Use with the Engstrom Respirator Acta Chrr Scand Suppl 245 (1959)

6 Engstrom, C-G et al Ventilation Nomogram for the New born and Small Children to be Used wsth the Engstrom Respirator Acta Anaesth Scard 6175 (1963)

7 Nunn, J F Predictors for Oxygen and Carbon Dioxide Levels durnng Anaesthesia Anaesthesia $17182(1962)$

8 Papadopoulos, C N \& Keats, A S The Metabolic Acidosis of Hyperventilation Produced by Controlled Respiration Anesthesiology 20156 (1959)

9 Dobirn, A B \& Song Young The Effect of Methoxyflurane-Nitrous Oxade Anaesthesia on Arterial $\mathrm{pH}$, Oxygen Saturation, $p_{\mathrm{3}} \mathrm{CO}_{2}$ and Plasma Bicarbonate in Man Anesthesiology $23601(1962)$

10 Hudon, F, Jacques, A, Déry, $\mathbb{R}$, Roux, J \& Ménard, Respiratory and Haemodynamic Effects of Methoxyflurane Anaesthessa Canad Anaesth Soc J 10442 (1963) 